\title{
SIKEPUL: Sistem Informasi untuk Administrasi Transaksi Jual Beli Pengepul Rongsokan Menggunakan Metode Waterfall
}

\section{SIKEPUL: An Information System for Administration of Sales and Purchase Transactions Junk Collectors Using the Waterfall Method}

\author{
Ika Dewi Rozaurrohmah ${ }^{1}$, Lutfi Syafirullah ${ }^{2}$, Oman Somantri ${ }^{3}$ \\ 1,2,3 Jurusan Teknik Informatika, Politeknik Negeri Cilacap, Indonesia \\ e-mail: ikadewirozaurohmah8f@gmail.com¹, syafirullah.lutfi@pnc.ac.id ${ }^{2}$,oman_mantri@yahoo.com ${ }^{3}$
}

\begin{abstract}
Abstrak
Saat ini pengusaha pengepul rongsok mengalami permasalahan yaitu tidak adanya pendataan untuk pemasok dan kegiatan transaksi rongsok. Selain itu proses pendataan administrasi masih dilakukan secara manual oleh admin, salah satunya adalah menggunakan nota saat melakukan transaksi rongsok dan saat mitra melakukan pembayaran kepada pengepul sering terjadi kesalahan komunikasi transaksi rongsok antara pemasok dan mitra. Untuk mengatasi permasalahan yang ada, maka pada penelitian ini diusulkan pembangunan sebuah sistem infromasi adminitrasi pengepul yang diberi nama SIKEPUL dengan menggunakan framework laravel. Metode dalam pengembangan Sistem yang digunakan adalah menggunakan metode waterfall. Hasil penelitian menunjukan bahwa sistem informasi SIKEPUL dapat mengatasi permasalahan yang dihadapi. Hasil keseluruhan kuisioner untuk 30 responden bahwa 20\% menyatakan sangat baik, $52 \%$ menyatakan baik, dan $28 \%$ menyatakan cukup terhadap sistem ini.
\end{abstract}

Kata Kunci: Pengepul Rongsok, Sikepul, Sistem Informasi, Waterfall, Framework Laravel

\begin{abstract}
Currently collector businessmen are experiencing problems, namely the absence of data collection for suppliers and collapsed transaction activities. In addition, the administrative data collection process is still carried out manually by the admin, , one of which is using notes when making junk transactions and when partners make payments to collectors, there are often communication errors in junk transactions between suppliers and partners often occur. In order to overcome the existing problems, this research proposes the development of a collector administration information system named SIKEPUL using the laravel framework. The method in developing the system used is the waterfall method. The results showed that the SIKEPUL information system could solve the problems faced. The overall results of the questionnaire for 30 respondents were that $20 \%$ said it was very good, $52 \%$ said it was good, and $28 \%$ said it was enough for this system.
\end{abstract}

Keywords: Junk Collectors, Sikepul, Information System, Waterfall, Laravel Framework.

\section{Pendahuluan}

Perkembangan teknologi informasi yang sangat pesat saat ini telah memberikan banyak manfaat dalam kemajuan diberbagai aspek. Penggunaan teknologi informasi oleh juga dapat membantu menyelesaikan pekerjaan dalam kehidupan sehari-hari. Sehingga manusia sebagai pengguna teknologi harus mampu memanfaatkan teknologi yang sedang berkembang. Perkembangan teknologi informasi semakin dibutuhkan salah satunya penggunaan sistem informasi administrasi dalam berbagai bidang antara lain bidang pendidikan, bidang swasta dan bidang usaha contohnya untuk admnistrasi pengepul rongsok (barang bekas).

Timbunan sampah di Indonesia terus meningkat dari tahun ke tahun. Di kota metropolitan, timbunan sampah diperkirakan rata-rata mencapai $>500$ ton/hari, sedangkan di kota sedang dengan jumlah penduduk $<$ 500orang/hari, timbulan sampah yang dihasilkan rata-rata sebanyak 100-300 ton/hari (Direktorat Pengembangan PLP, 2016). TPA merupakan tempat pembuangan sampah yang sering mendapatkan protes dari masyarakat sekitar. Namun baru sekitar 10\% sampah dari TPA yang dimanfaatkan dari banyaknya sampah yang ada, terdapat beberapa jenis sampah yang masih dapat didaur ulang atau bahkan dapat dijual ke pengepul rongsok [1].

Permasalahan yang dihadapi oleh setiap pengepul sampah yaitu tidak adanya pendataan untuk pemasok yang sudah menjual barangnya kepada pengepul. Kelemahan lainnya adalah kegiatan transaksi 
rongsok pengepul masih menggunakan cara manual dengan cara mencatat transaksi di buku, hal ini sering menimbulkan permasalahan dimana sering terjadi data hilang karena buku rusak sehingga riwayat transaksi tidak ditemukan. Tidak adanya pembuatan laporan pembukuan sehingga tidak dapat melihat kemajuan dari penjualan kepada mitra, dimana saat ini mitra harus menghubungi pihak pengepul untuk melakukan permintaan rongsok agar tahu apakah ada stok rongsok, jika ada stok maka pihak mitra mengambil rongsok di tempat pengepul, kemudian dilakukan proses transaksi yaitu pembuatan nota untuk bukti penjualan namun hal ini sering menimbulkan permasalahan dimana sering terjadi data hilang karena nota rusak sehingga riwayat transaksi tidak ada dan proses pembayaran dilakukan secara langsung atau melalui transfer bank. Saat mitra melakukan pembayaran kepada pengepul sering terjadi misscommunication antara pengepul dan mitra terkait konfirmasi pembayaran yaitu pada saat mitra melakukan pembayaran tidak langsung melakukan konfirmasi kepada pihak pengepul sehingga pihak pengepul tidak tahu bahwa mitra sudah melakukan pembayaran. Oleh karena itu untuk memudahkan pengepul dalam melakukan pengelolaan administrasi diperlukan sebuah sistem administrasi pengelolaan pengepul rongsok untuk melakukan pengelolaan data berupa data transaksi jual beli yang dilakukan.

Dalam pengelolaan barang bekas baik itu barang rongsok atau barang lainnya yang biasanya orang membuang dan dapat digunakan kembali seperti dilakukan oleh beberapa penelitian sebelumnya. Pengembangan sistem pengelolaan administrasi pengepul berbasis komputer dikembangkan untuk memudahkan administrasi datanya [2]. Penelitian lainnya adalah pembuatan sebuah sistem informasi keberadaan besi bekas dikembangkan, pada penelitian ini sistem dibuat dengan berbasiskan android sehingga lebih mudah digunakan [3]. Pentingnya dalam pencatatan laporan harian komponen rusak di perusahaan, maka penelitian dilakukan dengan merancang sebuah sistem informasi encatatan laporan harian komponen rusak yang dikembangkan di sebuah perusahaan [4].

Untuk pengembangan sebuah sistem informasi admisnitrasi yang baik, terdapat beberapa penelitian terdahulu yang sudah mengembangkan beberapa sistem informasi yang dikembangkan, seperti diantaranya pengembangan pengelolaan administrasi organisasi kemahasiswaan di STMIK STIKOM Indonesia. Penelitian tersebut menghasilkan penilaian tentang kondisi organisasi kemahasiswaan, yang didasarkan pada beberapa kriteria yaitu keaktifan anggota organisasi kemahasiswaan, jumlah kegiatan, partisipasi mahasiswa dalam kegiatan kemahasiswaan, dan kedisiplinan organisasi kemahasiswaan dalam hal administrasi. Penentuan kondisi ormawa dengan menggunakan metode Simple Additive Weighting [5]. Penelitian lainnya merancang sebuah sistem informasi akademik berbasis web. Sistem informasi administrasi akademik berbasis web ini, dapat memudahkan kegiatan-kegiatan di sekolah yang berkaitan dengan penginputan data nilai, data siswa, dan data guru. Dengan penerapan teknologi internet informasi ini lebih menarik, lebih cepat, tidak mengenal waktu, tidak terbatas oleh semua orang. Sistem Administarsi Akademik dibuat menggunakan bahasa pemrograman PHP [6].

Penelitian selanjutnya adalah mengembangkan sebuah sistem dengan cara analisa dan perancangan sistem informasi administrasi data pribadi dan nilai mahasiswa di perguruan tinggi. Tujuan dilakukan penelitian ini adalah untuk membuat suatu sistem komputerisasi yang lebih efektif dan efisien dilihat dari segi tingkat kecepatan dan ketepatan data yang diberikan pihak administrasi kepada mahasiswa. Metode pengembangan sistem yang digunakan dalam penelitian ini adalah metode Waterfall [7] . Penelitian lainya dikembangkan sebuah sistem administrasi pasien pada klinik keluarga Depok. Tujuan sistem informasi administrasi pasien pada Klinik Keluarga untuk mempercepat proses pengolahan data keadministrasian pasien sampai dengan proses pembuatan laporan, sehingga waktu yang dibutuhkan lebih singkat, efisiensi dalam manajemen biaya serta informasi yang dihasilkan lebih akurat. Metode pengembangan sistem yang digunakan dalam penelitian ini adalah metode waterfall [8].

Penelitian lainnya dilakukan smembuat sebuah sistem administrasi kependudukan pada desa Kota Karang. Sistem informasi ini mengelola data kependudukan akan ditambah pemrosesan untuk surat-surat keterangan, laporan pendukung lainnya, grafik serta perhitungan untuk jumlah penduduk berdasarkan yang dinginkan. Penelitian ini menghasilkan rancangan Sistem Informasi Kependudukan yang dapat melakukan pengelolaan data penduduk, pembuatan surat keterangan, surat pengantar serta laporan pendukung lainnya [9].

Berdasarkan beberapa penelitian terdahulu, pada penelitian ini dilakukan memiliki perbedaan dengan penelitian-penelitian sebelumnya yaitu sistem yang dibuat untuk pengelolaan pemasok rongsok untuk mengelola anggota (berlangganan) orang yang menjual rongsok, pengelolaan stok barang rongsok, pengelolaan pembukuan riwayat jual beli rongsok serta laporan pembukuan. Untuk mengoptimalisasi tampilan dan memudahkan dalam pembuatan sistem berbasis web ini dengan kelebihan yang dimiliki oleh framework [10], maka sistem dibuat menggunakan framework laravel untuk memudahkan penulis menyelesaian penelitian yang akan dibuat [11]. Tujuan dari penelitian ini adalah membangun sebuah sistem 
informasi administrasi pengepul rongsok berbasis website sehingga dapat mempermudah proses kinerja pengepul rongsok dalam pendataan pemasok (anggota), mempermudan transaksi penjualan dan pembelian pengepul, serta meningkatkan efektifitas kinerja dari kegiatan usaha pengepul.

\section{Metode Penelitian \\ Data dan Tools Penelitian}

Dalam melakukan analisis, penulis juga melakukan pengumpulan data baik melalui pustaka maupun berdasarkan masalah yang ada di lapangan. Dalam proses ini melakukan observasi yaitu pengamatan langsung terhadap alur proses yang sedang berjalan untuk memperoleh informasi yang nantinya akan diolah kedalam sistem serta wawancara denagn stakeholder. Data yang diambil secara langsung dari objek penelitian yang dibutuhkan dalam sistem ini adalah data admin, data mitra, data pemasok, data barang, data penjualan, dan data pembelian yang diambil ada tahun 2021 yang berasal dari salah satu perusahaan pemasok barang rongsok yaitu UD. Berkah Limbah Kabupaten Cilacap.

\section{Model Sistem Yang Diusulkan}

Pada penelitian ini diusulkan sebuah sistem dimana kebutuhan antarmuka jaringan user bertindak sebagai client yang dapat mengakses data pada server menggunakan perangkat komputer serta printer dan terdapat user yang mengakses data server menggunakan handphone, untuk model sistem yang diusulkan diperlihatkan pada Gambar 1.

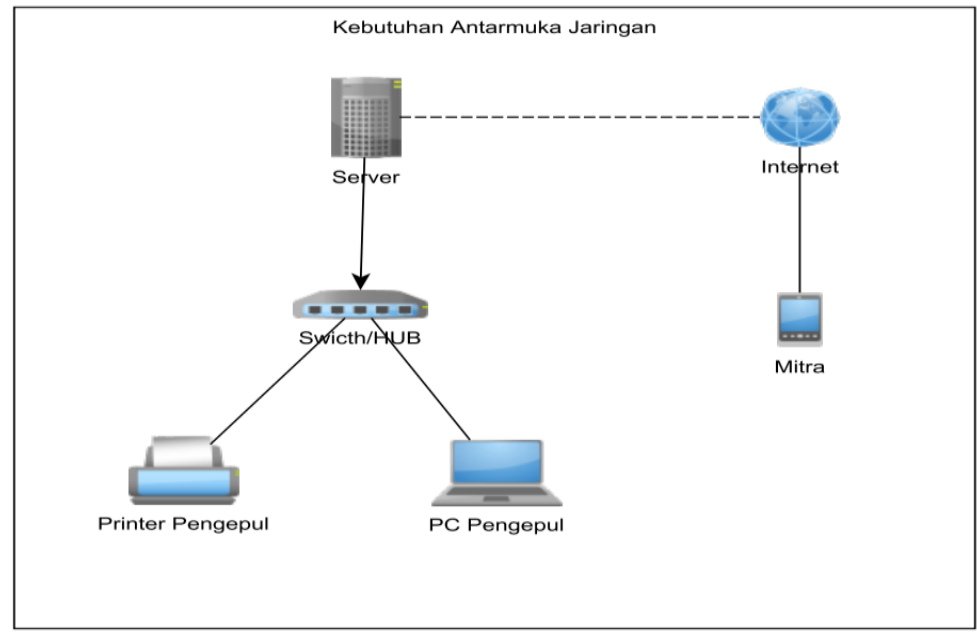

Gambar 1. Model yang diusulkan untuk sistem

\section{Metode Pengembangan Sistem}

Metodel Pengembangan Sistem yang digunakan adalah metode waterfall. Metode waterfall merupakan metode yang sering digunakan oleh penganalisa sistem pada umumnya. Metode waterfall adalah pengerjaan dari suatu sistem yang dilakukan secara berurutan [12].

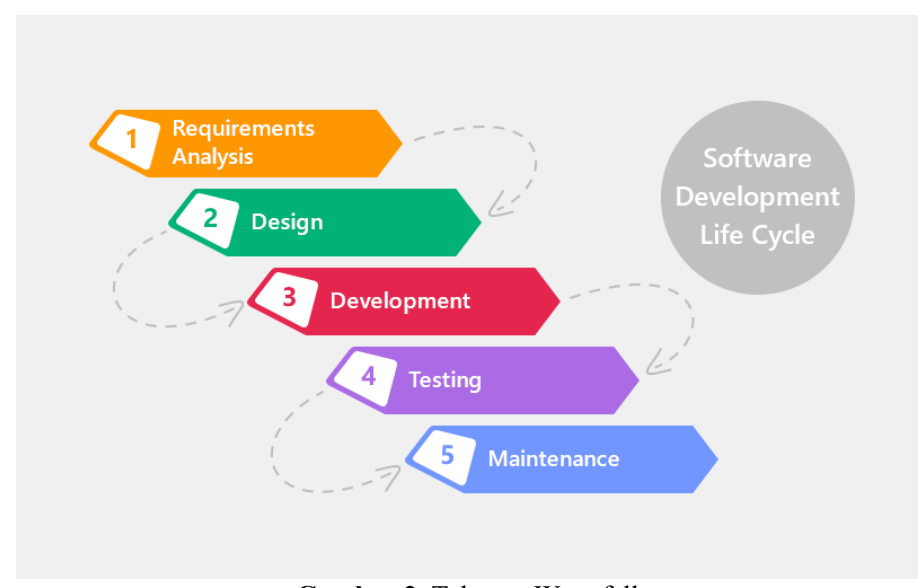

Gambar 2. Tahapan Waterfall 
Pada gambar 2 memperlihatkan tahapan pengembangan sistem yang dilakukan, adapun tahapannya adalah sebagai berikut:

- Analisis Kebutuhan dan Perangkat Lunak, Pada tahap ini lebih diintensifkan dan difokuskan pada perangkat lunak fungsi yang dibutuhkan, perilaku, daya guna dan tampilan layar dari perangkat lunak yang dikembangkan.

- Perancangan (Design).

- Pembuatan Kode (Coding).

- Pengujian (Testing).

- Pemeliharaan (Maintenance).

\section{Evaluasi dan Uji Sistem}

Untuk melihat apakah sistem yang telah dibuat sudah sesuai dengan tujuan awal pembuatan dan layak untuk dipergunakan, pada pengemabnagan ssitem ini menggunakan metode black box.

\section{Hasil dan Pembahasan \\ Perancangan Sistem}

Pada pengembangan sistem ini UML [13] digunakan untuk merancang model dalam sistem, dan digunakan untuk aplikasi perangkat lunak dan aplikasi tersebut dapat bejalan diperangkat keras. Pada tahap perancangan dibuat diagram alur sistem yang sedang berjalan dan alur sistem yang akan dikembangkan menggunakan flowchart. Untuk analisis sistem yang dikembangkan dapat dilihat pada Gambar 3. Proses pemasok yang menyerahkan barang kepada pengepul kemudian dilakukan proses pembayaran untuk pemasok. Proses mitra meminta stok barang kepada pengepul jika tidak ada maka selesai dan jika ada maka pengepul melakukan penjualan barang ke mitra. Pengepul akan mencatat penjualan dan mitra melakukan pembayaran.Proses pemasok menyerahkan barang ke pengepul yang nantinya data disimpan oleh sistem. Sistem akan melakukan perhitungan kemudia kwitansi akan ditampilkan. Admin akan mencetak kwitansi dan melakukan pembayaran kepemasok.

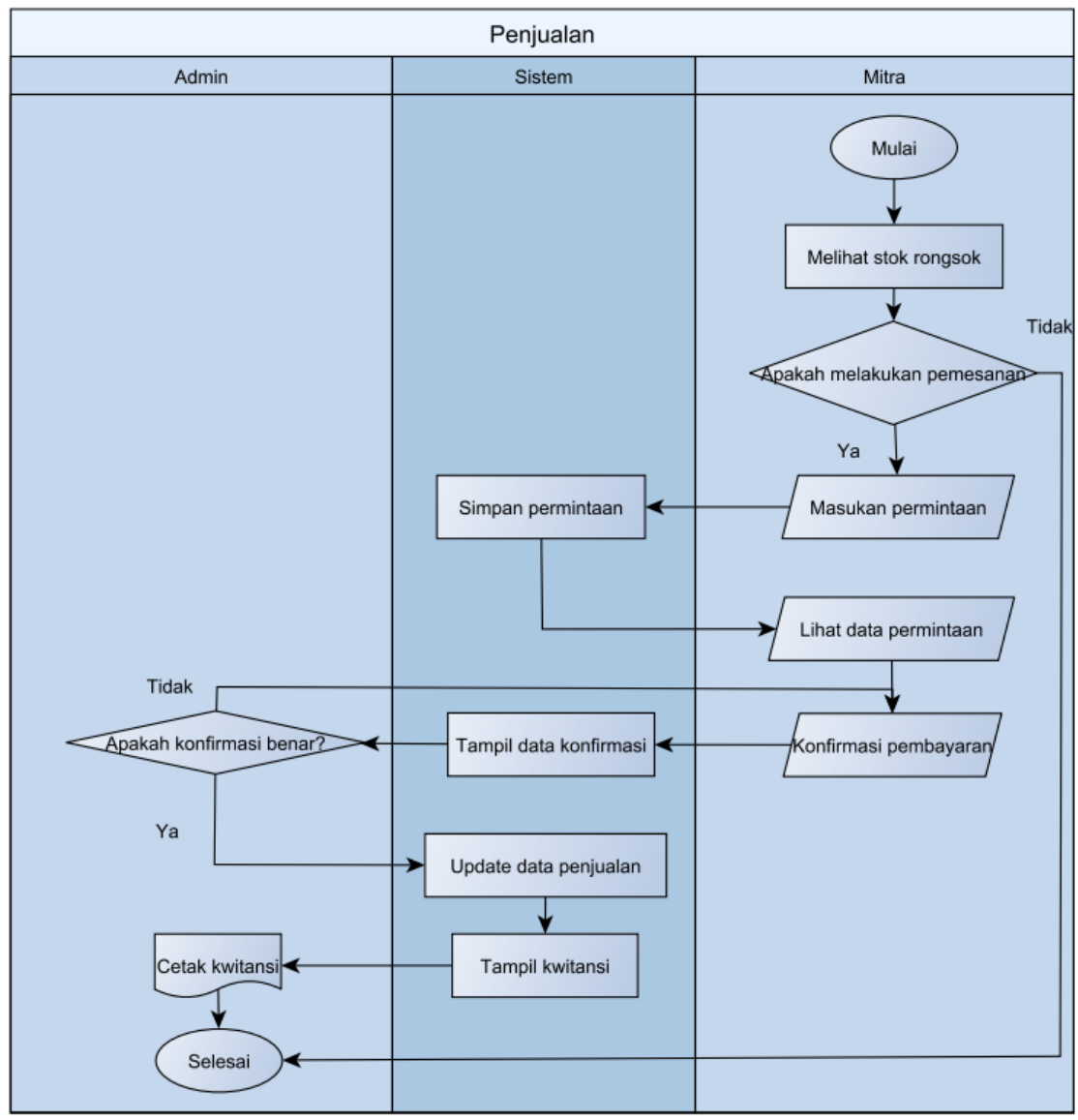

Gambar 3. Diagram Alur Sistem Yang Akan Dikembangkan 


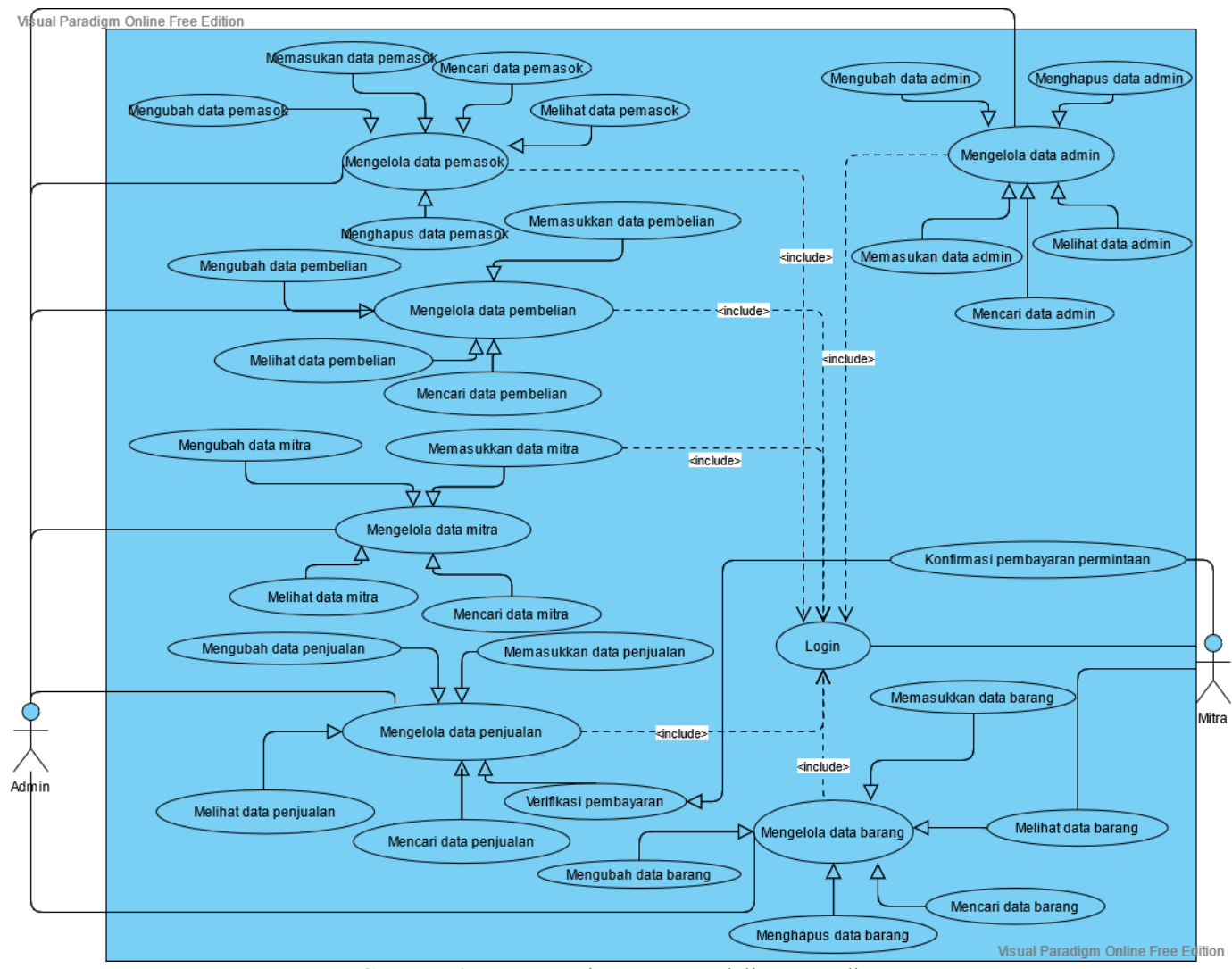

Gambar 4. Use case Sistem Pengendalian Persediaan Barang

Proses mitra dapat melihat stok rongsok, jika stok ada maka mitra melakukan permintaan barang ke pengepul. Mitra memasukan data permintaan sistem akan menyimpan data permintaan mitra. Mitra dapat melihat data permintaan dan kemudian melakukan konfirmasi pembayaran. Admin akan verifikasi pembayaran mitra jika benar tampil kwitansi dan admin akan mencetak kwitansi. Pada Gambar 4 adalah use case Sistem Pengendalian Persediaan Barang Menggunakan Metode EOQ dan ROP berbasis Web sebagai media informasi.

\section{Implementasi Sistem}

Pada tahap ini hasil penelitian dari Sistem Administrasi Pengepul Rongsok. Implementasi ini menampilkan hasil screenshot sistem. Halaman Welcome berfungsi sebagai tampilan awal sebelum login dilakukan. Jika akan melakukan login maka klil login dibagian pojok kanan atas. Tampilan welcome ada Sistem Adminitrasi Pengepul Rongsok pada UD. Berkah Limbah dapat dilihat pada Gambar 5, terdapat button login yang digunakan untuk login mitra dan admin.

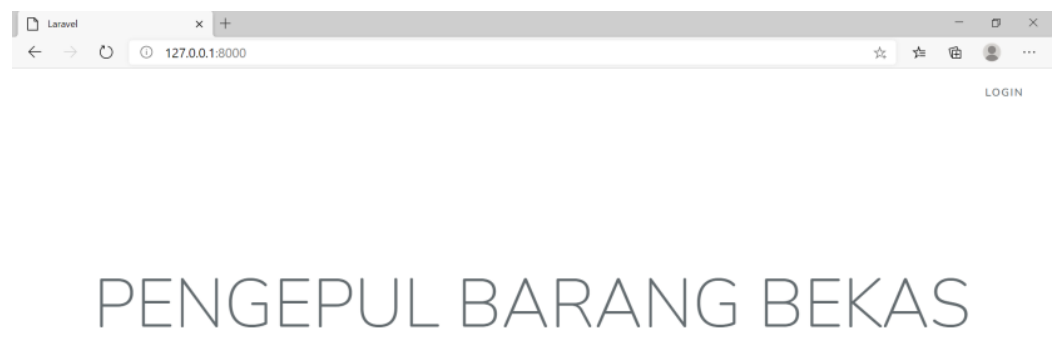

a 0 Type here to search

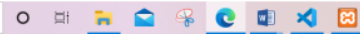

Gambar 5. Implementasi Halaman Welcome

JINITA Vol. 3, No. 2, Desember 2021 
Halaman Login berfungsi untuk masuk ke dalam sistem dengan cara memasukkan username dan password yang valid atau sesuai dengan akun setiap pengguna yang sudah terdaftar di sistem. Halaman Dashboard berisi menu file manajemen data. Menu muncul sesuai dengan hak akses setiap user ditunjukan pada Gambar 6.

Halaman data admin digunakan untuk mengelola data admin atau user yang terkait dengan sistem dan dikelola oleh Admin. Tampilan halaman data admin dapat dilihat pada Gambar 7. Halaman data mitra digunakan untuk mengelola data mitra dan dikelola oleh admin, dapat dilihat pada Gambar 8. Halaman data pemasok digunakan untuk mengelola data pemasok dan dikelola oleh admin, dapat dilihat pada Gambar 9.
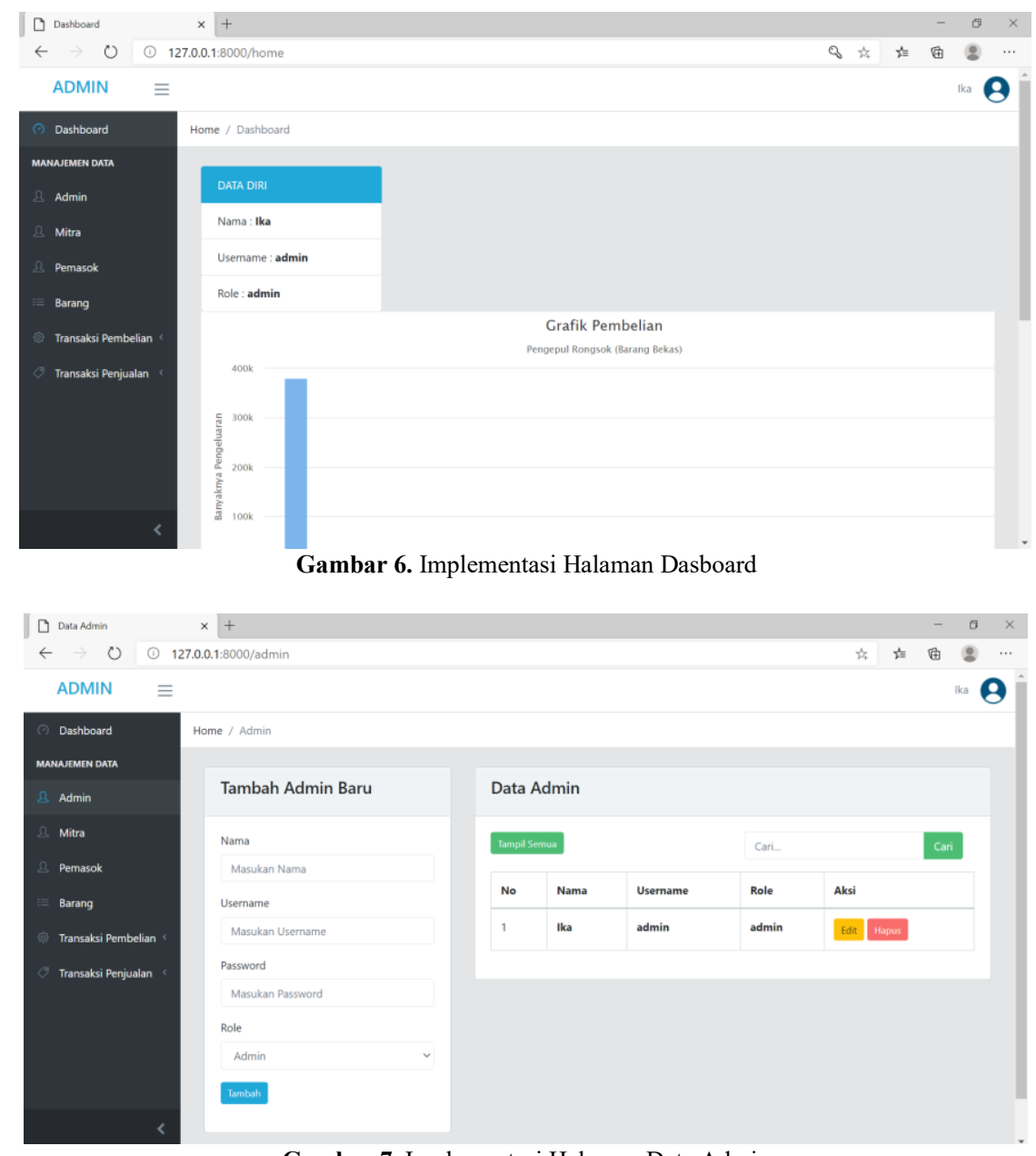

Gambar 7. Implementasi Halaman Data Admin

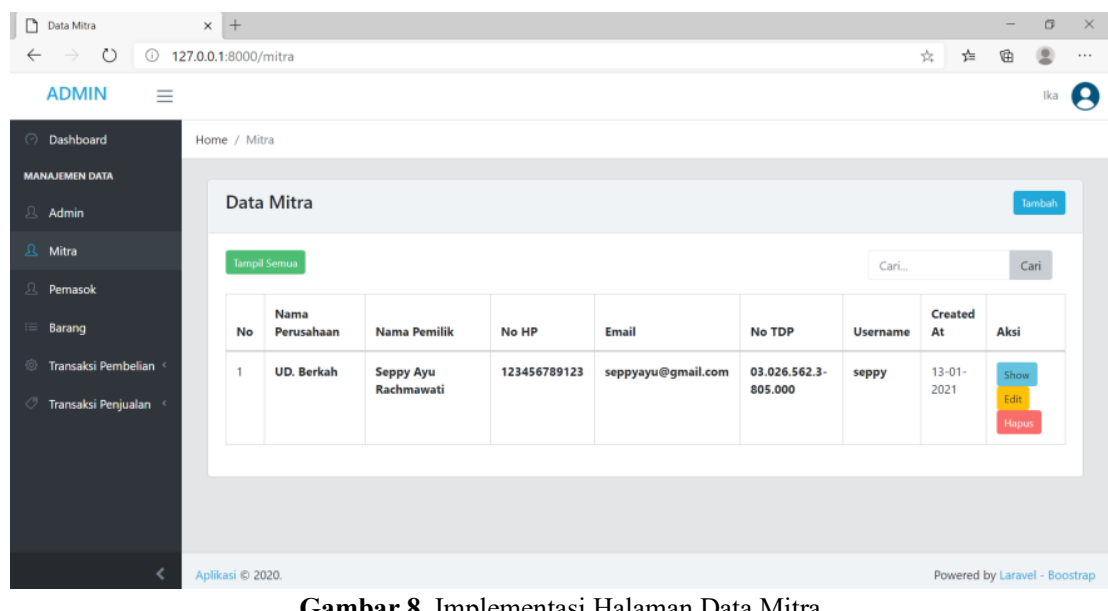

Gambar 8. Implementasi Halaman Data Mitra 


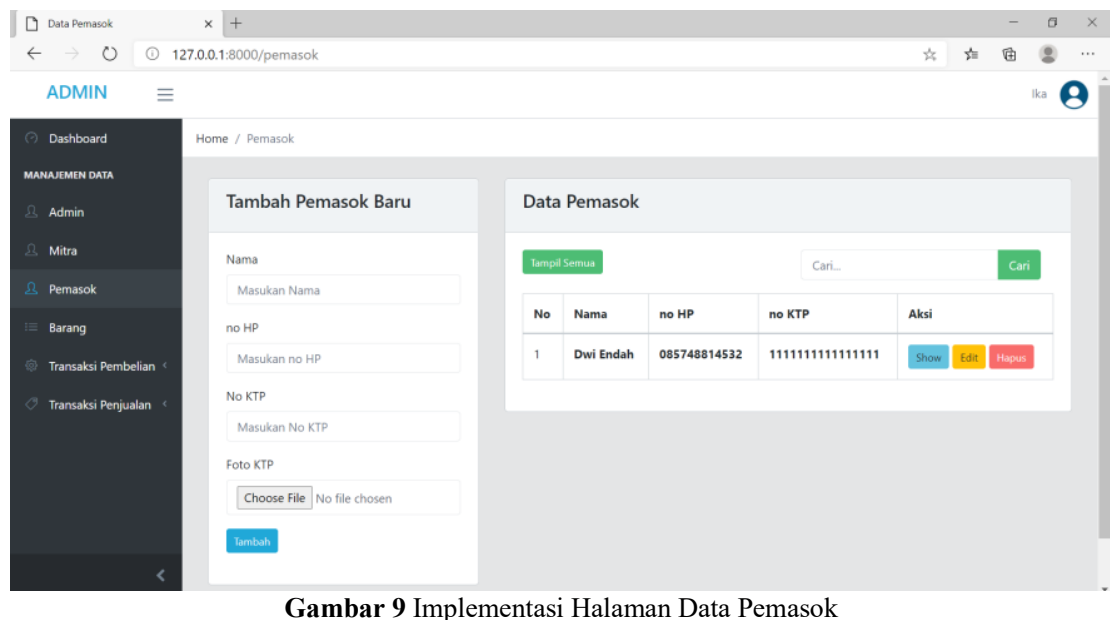

Halaman Data Barang digunakan untuk mengelola data barang dan dikelola oleh admin. Halaman Data Pembelian. Halaman data input pembelian digunakan untuk melakukan proses transaksi pembelian rongsok (barang) antara pengepul dan pemasok. Tampilan halaman data input pembelian dapat dilihat pada Gambar 10. Halaman data input penjualan digunakan untuk melakukan proses transaksi penjualan rongsok (barang) antara pengepul dan mitra. Tampilan halaman data input penjualan dapat dilihat pada Gambar 11. Halaman login mitra harus menggunakan username dan password unuk login dapat dilihat pada Gambar 12.

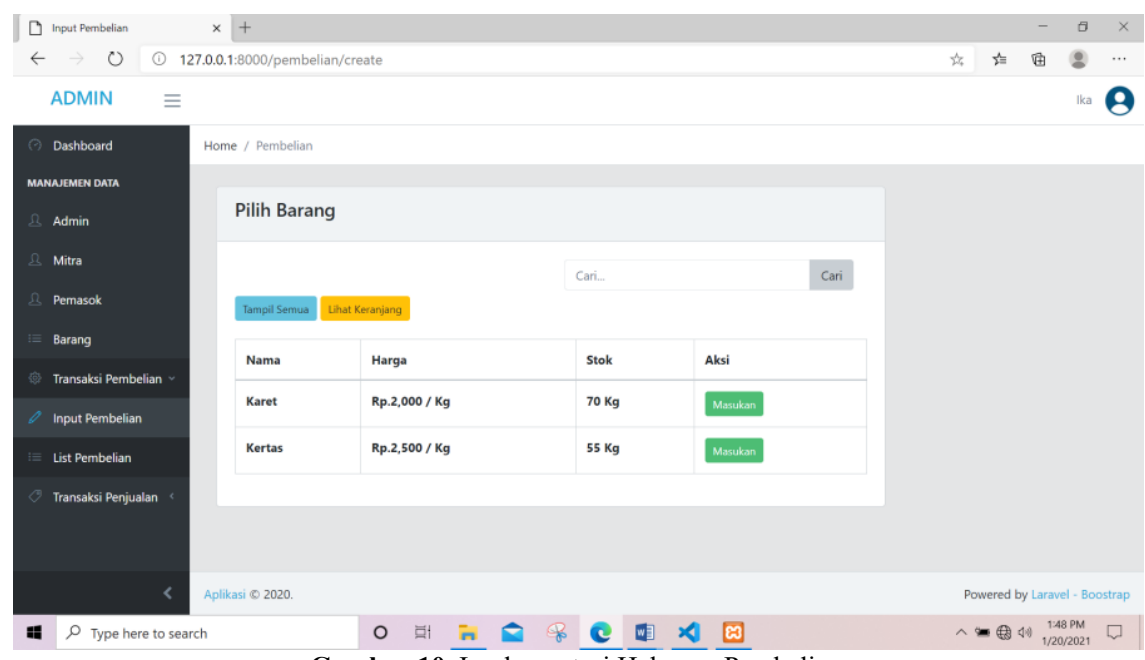

Gambar 10. Implementasi Halaman Pembelian.

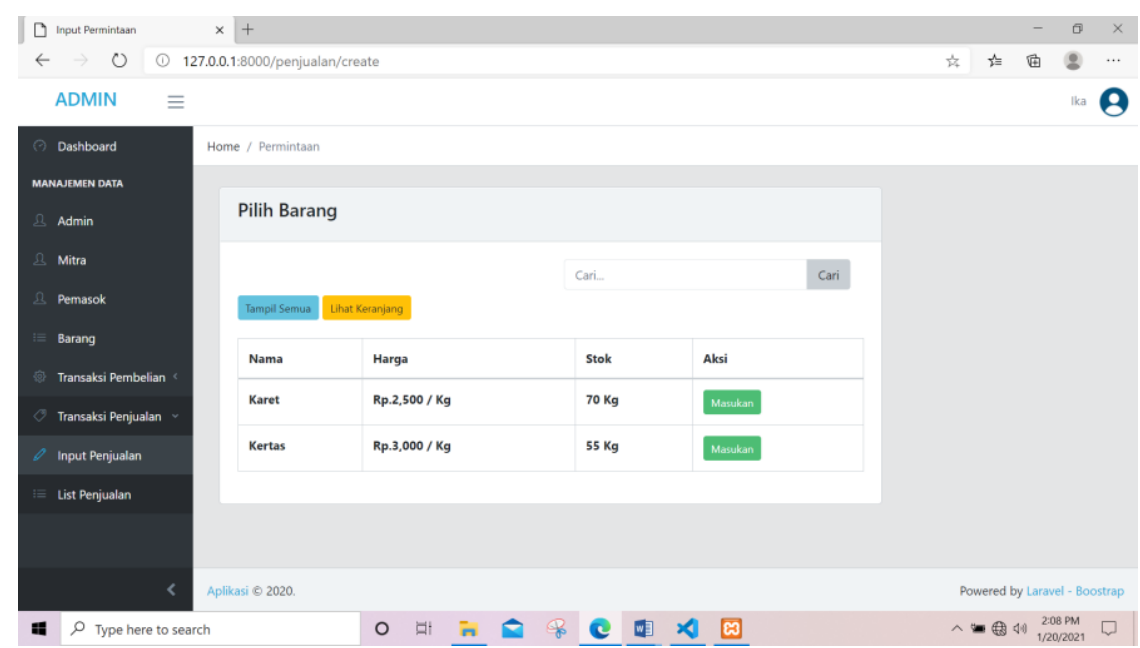

Gambar 11. Halaman EOQ 


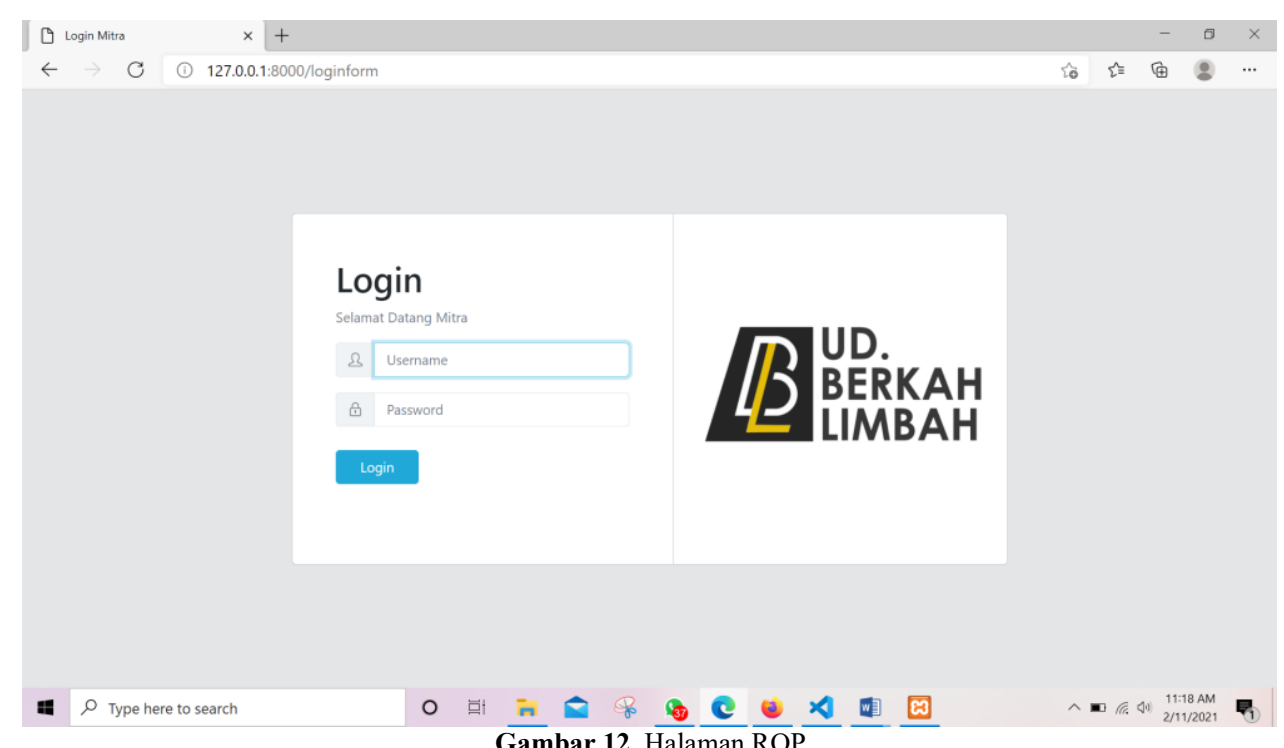

\section{Evaluasi dan Uji Sistem}

Metode pengujian yang dilakukan dalam pembuatan Sistem Pengendalian Persediaan Barang ini menggunakan metode blackbox. Metode pengujian blackbox dilakukan untuk memperoleh gambaran kesesuaian antara input dan output. Pengujian ini juga mengacu kepada kebutuhan fungsional dari perangkat lunak. Berdasarkan hasil pengujian yang dilakukan, hasil uji dari sistem diperlihatkan pada tabel pengujian perangkat lunak yang dapat dilihat pada Tabel 1 .

\begin{tabular}{|c|c|c|c|c|}
\hline No & Fungsionalitas & Kondisi & Waktu & Hasil \\
\hline 1 & Login & $\begin{array}{l}\text { Login Admin } \\
\text { Login Mitra }\end{array}$ & $\begin{array}{l}\text { 21 Januari } 2021 \\
21 \text { Januari } 2021\end{array}$ & $\begin{array}{l}\text { Berhasil } \\
\text { Berhasil }\end{array}$ \\
\hline 2 & Tambah data & $\begin{array}{l}\text { Tambah Admin } \\
\text { Tambah Mitra } \\
\text { Tambah Pemasok } \\
\text { Tambah Barang } \\
\text { Tambah Pembelian } \\
\text { Tambah Pembelian }\end{array}$ & $\begin{array}{l}21 \text { Januari } 2021 \\
21 \text { Januari } 2021 \\
21 \text { Januari } 2021 \\
21 \text { Januari } 2021 \\
21 \text { Januari } 2021 \\
\text { 21 Januari } 2021\end{array}$ & $\begin{array}{l}\text { Berhasil } \\
\text { Berhasil } \\
\text { Berhasil } \\
\text { Berhasil } \\
\text { Berhasil } \\
\text { Berhasil }\end{array}$ \\
\hline 3 & Ubah Data & $\begin{array}{l}\text { Ubah Admin } \\
\text { Ubah Mitra } \\
\text { Ubah Pemasok } \\
\text { Ubah Barang }\end{array}$ & $\begin{array}{l}\text { 21 Januari } 2021 \\
21 \text { Januari } 2021 \\
\text { 21 Januari } 2021 \\
\text { 21 Januari } 2021\end{array}$ & $\begin{array}{l}\text { Berhasil } \\
\text { Berhasil } \\
\text { Berhasil } \\
\text { Berhasil }\end{array}$ \\
\hline 4 & Hapus data & $\begin{array}{l}\text { Hapus Admin } \\
\text { Hapus Mitra } \\
\text { Hapus Pemasok } \\
\text { Hapus Barang }\end{array}$ & $\begin{array}{l}\text { 21 Januari } 2021 \\
21 \text { Januari } 2021 \\
21 \text { Januari } 2021 \\
\text { 21 Januari } 2021\end{array}$ & $\begin{array}{l}\text { Berhasil } \\
\text { Berhasil } \\
\text { Berhasil } \\
\text { Berhasil }\end{array}$ \\
\hline 5 & Lihat data & $\begin{array}{l}\text { Lihat Admin } \\
\text { Lihat Mitra } \\
\text { Lihat Pemasok } \\
\text { Lihat barang } \\
\text { Lihat Pembelian } \\
\text { Lihat Penjualan }\end{array}$ & $\begin{array}{l}\text { 21 Januari } 2021 \\
21 \text { Januari } 2021 \\
\text { 21 Januari } 2021 \\
\text { 21 Januari } 2021 \\
\text { 21 Januari } 2021 \\
\text { 21 Januari } 2021\end{array}$ & $\begin{array}{l}\text { Berhasil } \\
\text { Berhasil } \\
\text { Berhasil } \\
\text { Berhasil } \\
\text { Berhasil } \\
\text { Berhasil }\end{array}$ \\
\hline 6 & Lihat detail & $\begin{array}{l}\text { Lihat Detail Pembelian } \\
\text { Lihat Detail Penjualan }\end{array}$ & $\begin{array}{l}21 \text { Januari } 2021 \\
21 \text { Januari } 2021\end{array}$ & $\begin{array}{l}\text { Berhasil } \\
\text { Berhasil }\end{array}$ \\
\hline
\end{tabular}

Penulis telah dilakukan pengujian fungsionalitas sistem berdasarkan Tabel . Berikut hasil pengujian dari Sistem Administrasi Pengepul Rongsok pada UD. Berkah Limbah. Dari beberapa penguji yaitu admin 
dan pemilik yang melakukan pengujian dari fungsi login dinyatakan berhasil dan sesuai dengan yang diharapkan. Dalam pengujian login, user melakukan login ke dalam sistem. Terdapat dua kondisi dalam fungsi login yaitu kondisi data normal dan kondisi data salah. Kondisi normal pada saat user memasukan data yang valid, maka akan masuk ke halaman awal atau dashboard dari sistem, sedangkan kondisi salah pada saat user memasukan data yang salah, maka akan muncul pesan "Username/Password salah!" dan tidak dapat masuk ke halaman awal atau dashboard dari sistem. Pengujian dapat dilihat pada Tabel 2.

Tabel 2. Hasil Pengujian Login

\begin{tabular}{|c|c|c|c|c|}
\hline No. & Data Masukan & Yang Diharapkan & Pengamatan & Kesimpulan \\
\hline 1. & $\begin{array}{l}\text { Memasukkan username dan } \\
\text { password yang sesuai }\end{array}$ & $\begin{array}{l}\text { Login berhasil dan masuk ke halaman } \\
\text { utama }\end{array}$ & $\begin{array}{l}\text { Login berhasil dan masuk ke } \\
\text { halaman utama }\end{array}$ & $\begin{array}{l}{[\checkmark] \text { Berhasil }} \\
{[\text { ] Gagal }}\end{array}$ \\
\hline 2. & Data Masukan & Yang Diharapkan & Pengamatan & Kesimpulan \\
\hline & $\begin{array}{l}\text { Memasukkan username dan } \\
\text { password yang salah }\end{array}$ & $\begin{array}{l}\text { Muncul pesan username atau password } \\
\text { salah }\end{array}$ & $\begin{array}{l}\text { Muncul pesan username atau } \\
\text { password salah }\end{array}$ & $\begin{array}{l}{[\vee] \text { Berhasil }} \\
{[\text { ] Gagal }}\end{array}$ \\
\hline 3. & Menginputkan data admin & $\begin{array}{l}\text { Data admin dapat tersimpan dan muncul } \\
\text { pesan data berhasil disimpan }\end{array}$ & $\begin{array}{l}\text { Data admin tersimpan ke } \\
\text { database }\end{array}$ & $\begin{array}{l}{[\checkmark] \text { Berhasil }} \\
{[\quad] \text { Gagal }}\end{array}$ \\
\hline 4. & $\begin{array}{l}\text { Menginputkan data admin } \\
\text { secara tidak lengkap }\end{array}$ & $\begin{array}{l}\text { Tidak dapat menyimpan data admin dan } \\
\text { muncul pesan }\end{array}$ & $\begin{array}{l}\text { Data admin tidak tersimpan ke } \\
\text { database }\end{array}$ & [ $\checkmark$ ] Berhasil \\
\hline 5 & Menginputkan data admin & $\begin{array}{l}\text { Data admin dapat diubah, tersimpan ke } \\
\text { database serta menampilkan pesan }\end{array}$ & $\begin{array}{l}\text { Data admin berhasil diubah dan } \\
\text { tersimpan ke database }\end{array}$ & [ $\checkmark$ ] Berhasil \\
\hline 6. & $\begin{array}{l}\text { Menginputkan data admin } \\
\text { secara tidak lengkap }\end{array}$ & $\begin{array}{l}\text { Tidak dapat mengubah data admin dan } \\
\text { muncul pesan }\end{array}$ & $\begin{array}{l}\text { Data admin tidak berhasil } \\
\text { diubah }\end{array}$ & 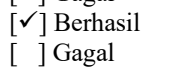 \\
\hline 7. & Memilih menu admin & Dapat menampilkan data admin & Data admin dapat ditampilkan & $\begin{array}{l}{[\checkmark] \text { Berhasil }} \\
{[\text { ] Gagal }}\end{array}$ \\
\hline 8. & $\begin{array}{l}\text { Mengklik button hapus pada } \\
\text { data admin yang akan } \\
\text { dihapus }\end{array}$ & $\begin{array}{l}\text { Data admin dapat dihapus dan terhapus } \\
\text { dari database serta menampilkan pesan } \\
\text { data berhasil dihapus }\end{array}$ & $\begin{array}{l}\text { Data admin berhasil dihapus } \\
\text { dari database }\end{array}$ & $\begin{array}{l}{[\checkmark] \text { Berhasil }} \\
{[\text { ] Gagal }}\end{array}$ \\
\hline 9. & Menginputkan data mitra & $\begin{array}{l}\text { Data mitra dapat tersimpan dan muncul } \\
\text { pesan data berhasil disimpan }\end{array}$ & $\begin{array}{l}\text { Data mitra tersimpan ke } \\
\text { database }\end{array}$ & $\begin{array}{l}{[\checkmark] \text { Berhasil }} \\
{[\text { ] Gagal }}\end{array}$ \\
\hline 10. & $\begin{array}{l}\text { Menginputkan data mitra } \\
\text { secara tidak lengkap }\end{array}$ & $\begin{array}{l}\text { Tidak dapat menyimpan data mitra dan } \\
\text { muncul pesan }\end{array}$ & $\begin{array}{l}\text { Data mitra tidak tersimpan ke } \\
\text { database }\end{array}$ & $\begin{array}{l}{[\checkmark] \text { Berhasil }} \\
{[\text { ] Gagal }}\end{array}$ \\
\hline 11. & Menginputkan data mitra & $\begin{array}{l}\text { Data mitra dapat diubah, tersimpan ke } \\
\text { database serta menampilkan pesan }\end{array}$ & $\begin{array}{l}\text { Data mitra berhasil diubah dan } \\
\text { tersimpan ke database }\end{array}$ & $\begin{array}{l}{[\checkmark] \text { Berhasil }} \\
{[\quad] \text { Gagal }}\end{array}$ \\
\hline 12. & $\begin{array}{l}\text { Menginputkan data mitra } \\
\text { secara tidak lengkap }\end{array}$ & $\begin{array}{l}\text { Tidak dapat mengubah data mitra dan } \\
\text { muncul pesan }\end{array}$ & $\begin{array}{l}\text { Data mitra tidak berhasil } \\
\text { diubah }\end{array}$ & $\begin{array}{l}{[\checkmark] \text { Berhasil }} \\
{[\quad] \text { Gagal }}\end{array}$ \\
\hline 13. & Memilih menu mitra & Dapat menampilkan data mitra & Data mitra dapat ditampilkan & 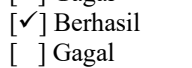 \\
\hline 14. & $\begin{array}{l}\text { Mengklik button hapus pada } \\
\text { data mitra yang akan dihapus }\end{array}$ & $\begin{array}{l}\text { Data mitra dapat dihapus dan terhapus } \\
\text { dari database serta menampilkan pesan } \\
\text { data berhasil dihapus }\end{array}$ & $\begin{array}{l}\text { Data mitra berhasil dihapus } \\
\text { dari database }\end{array}$ & $\begin{array}{l}{[\checkmark] \text { Berhasil }} \\
{[\text { ] Gagal }}\end{array}$ \\
\hline 15. & Menginputkan data pemasok & $\begin{array}{l}\text { Data pemasok dapat tersimpan dan } \\
\text { muncul pesan data berhasil disimpan }\end{array}$ & $\begin{array}{l}\text { Data pemasok tersimpan ke } \\
\text { database }\end{array}$ & $\begin{array}{l}{[\vee] \text { Berhasil }} \\
{[\quad] \text { Gagal }}\end{array}$ \\
\hline 16. & $\begin{array}{l}\text { Menginputkan data pemasok } \\
\text { secara tidak lengkap }\end{array}$ & $\begin{array}{l}\text { Tidak dapat menyimpan data pemasok } \\
\text { dan muncul pesan }\end{array}$ & $\begin{array}{l}\text { Data pemasok tidak tersimpan } \\
\text { ke database }\end{array}$ & 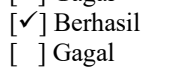 \\
\hline 17. & Menginputkan data pemasok & $\begin{array}{l}\text { Data pemasok dapat diubah, tersimpan } \\
\text { ke database serta menampilkan pesan }\end{array}$ & $\begin{array}{l}\text { Data pemasok berhasil diubah } \\
\text { dan tersimpan ke database }\end{array}$ & $\begin{array}{l}{[\checkmark] \text { Berhasil }} \\
{[\text { ] Gagal }}\end{array}$ \\
\hline 18. & $\begin{array}{l}\text { Menginputkan data pemasok } \\
\text { secara tidak lengkap }\end{array}$ & $\begin{array}{l}\text { Tidak dapat mengubah data pemasok } \\
\text { dan muncul pesan }\end{array}$ & $\begin{array}{l}\text { Data pemasok tidak berhasil } \\
\text { diubah }\end{array}$ & 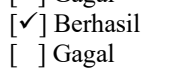 \\
\hline 19 & Memilih menu pemasok & Dapat menampilkan data pemasok & $\begin{array}{l}\text { Data pemasok dapat } \\
\text { ditampilkan }\end{array}$ & [ ] ] Gagal \\
\hline 20. & $\begin{array}{l}\text { Mengklik button hapus pada } \\
\text { data pemasok yang akan } \\
\text { dihapus }\end{array}$ & $\begin{array}{l}\text { Data pemasok dapat dihapus dan } \\
\text { terhapus dari database serta } \\
\text { menampilkan pesan data berhasil } \\
\text { dihapus }\end{array}$ & $\begin{array}{l}\text { Data pemasok berhasil dihapus } \\
\text { dari database }\end{array}$ & [ ] Gagal \\
\hline 21. & Menginputkan data barang & $\begin{array}{l}\text { Data barang dapat tersimpan dan muncul } \\
\text { pesan data berhasil disimpan }\end{array}$ & $\begin{array}{l}\text { Data barang tersimpan ke } \\
\text { database }\end{array}$ & $\begin{array}{l}{[\checkmark \text { B Berhasil }} \\
{[\text { ] Gagal }}\end{array}$ \\
\hline 22. & $\begin{array}{l}\text { Menginputkan data barang } \\
\text { secara tidak lengkap }\end{array}$ & $\begin{array}{l}\text { Tidak dapat menyimpan data barang dan } \\
\text { muncul pesan }\end{array}$ & $\begin{array}{l}\text { Data barang tidak tersimpan ke } \\
\text { database }\end{array}$ & [ ] B Bagal \\
\hline 23. & Menginputkan data barang & $\begin{array}{l}\text { Data barang dapat diubah, tersimpan ke } \\
\text { database serta menampilkan pesan }\end{array}$ & $\begin{array}{l}\text { Data barang berhasil diubah } \\
\text { dan tersimpan ke database }\end{array}$ & $\begin{array}{l}{[\checkmark] \text { Berhasil }} \\
{[\text { ] Gagal }}\end{array}$ \\
\hline 24. & $\begin{array}{l}\text { Menginputkan data barang } \\
\text { secara tidak lengkap }\end{array}$ & $\begin{array}{l}\text { Tidak dapat mengubah data barang dan } \\
\text { muncul pesan }\end{array}$ & $\begin{array}{l}\text { Data barang tidak berhasil } \\
\text { diubah }\end{array}$ & $\begin{array}{l}{[\checkmark] \text { Berhasil }} \\
{[\text { ] Gagal }}\end{array}$ \\
\hline 25. & Memilih menu barang & Dapat menampilkan data barang & Data barang dapat ditampilkan & $\begin{array}{l}{[\checkmark] \text { Berhasil }} \\
{[\text { ] Gagal }}\end{array}$ \\
\hline 26. & $\begin{array}{l}\text { Mengklik button hapus pada } \\
\text { data barang yang akan } \\
\text { dihapus }\end{array}$ & $\begin{array}{l}\text { Data barang dapat dihapus dan terhapus } \\
\text { dari database serta menampilkan pesan } \\
\text { data berhasil dihapus }\end{array}$ & $\begin{array}{l}\text { Data barang berhasil dihapus } \\
\text { dari database }\end{array}$ & {$\left[{ }^{\vee}\right]$ Berhasil } \\
\hline 27. & $\begin{array}{l}\text { Menginputkan data } \\
\text { pembelian }\end{array}$ & $\begin{array}{l}\text { Data pembelian dapat tersimpan dan } \\
\text { muncul pesan data berhasil disimpan }\end{array}$ & $\begin{array}{l}\text { Data pembelian tersimpan ke } \\
\text { database }\end{array}$ & $\begin{array}{l}{\left[\sqrt{ }{ }^{\vee}\right] \text { Berhasil }} \\
{[\text { ] Gagal }}\end{array}$ \\
\hline 28. & $\begin{array}{l}\text { Menginputkan data } \\
\text { pembelian secara tidak } \\
\text { lengkap }\end{array}$ & $\begin{array}{l}\text { Tidak dapat menyimpan data pembelian } \\
\text { dan muncul pesan }\end{array}$ & $\begin{array}{l}\text { Data pembelian tidak tersimpan } \\
\text { ke database }\end{array}$ & $\begin{array}{l}{[\checkmark] \text { Berhasil }} \\
{[\quad] \text { Gagal }}\end{array}$ \\
\hline
\end{tabular}




\begin{tabular}{|c|c|c|c|c|}
\hline No. & Data Masukan & Yang Diharapkan & Pengamatan & Kesimpulan \\
\hline $\begin{array}{l}29 . \\
30 .\end{array}$ & $\begin{array}{l}\text { Menginputkan data } \\
\text { pembelian } \\
\text { Menginputkan data } \\
\text { pembelian secara tidak } \\
\text { lengkap }\end{array}$ & $\begin{array}{l}\text { Data pembelian dapat diubah, tersimpan } \\
\text { ke database serta menampilkan pesan } \\
\text { Tidak dapat mengubah data pembelian } \\
\text { dan muncul pesan }\end{array}$ & $\begin{array}{l}\text { Data pembelian berhasil diubah } \\
\text { dan tersimpan ke database } \\
\text { Data pembelian tidak berhasil } \\
\text { diubah }\end{array}$ & $\begin{array}{l}\checkmark \text { ] Berhasil } \\
{[\text { ] Gagal }} \\
{[\checkmark] \text { Berhasil }} \\
{[\text { ] Gagal }}\end{array}$ \\
\hline
\end{tabular}

Hasil analisis kuisioner Sistem Informasi Administrasi Pengepul Rongsok pada UD. Berkah Limbah menunjukan fungsionalitas sistem yang telah dibangun dalam mendukung proses pengendalian persediaan barang yang merupakan tujuan utama dibangunnya sistem ini. Hasil penilaian dapat dilihat pada Tabel 3 dengan $\mathrm{SK}=$ Sangat Kurang, $\mathrm{K}=$ Kurang, $\mathrm{C}=$ Cukup, $\mathrm{B}=\mathrm{Baik}$, dan $\mathrm{SB}=$ Sangat Baik.

Table 3. Hasil Analisis Kuisioner

\begin{tabular}{|c|c|c|c|c|c|c|}
\hline No & Indikator & SK & $\mathbf{K}$ & $\mathbf{C}$ & B & SB \\
\hline 1 & $\begin{array}{l}\text { Sistem membantu admin untuk mempermudah proses pengelolaan data pemasok, data mitra, data barang, data } \\
\text { pembelian dan data penjualan }\end{array}$ & 0 & 0 & 6 & 14 & 10 \\
\hline 2 & Sistem membantu admin dalam transaksi dan pembukuan jual beli rongsok (barang bekas) & 0 & 0 & 7 & 19 & 4 \\
\hline 3 & Memudahkan mitra dalam melakukan permintaan rongsok (barang bekas & 0 & 0 & 12 & 14 & 4 \\
\hline 4 & Memudahkan mitra dalam proses pembayaran dan konfirmasi pembayaran & 0 & 0 & 9 & 15 & 6 \\
\hline \multicolumn{2}{|r|}{ Total: } & 0 & 0 & 34 & 62 & 24 \\
\hline
\end{tabular}

Hasil rekapitulasi penilaian dari 30 responden terhadap Sistem untuk memudahkan admin pengepul dalam pengelolaan data didapatkan hasil yakni 10 dari 30 responden (33\%) menyatakan sangat baik, 14 dari 30 responden $(47 \%)$ menyatakan baik dan 6 dari 30 responden (20\%) menyatakan cukup. Grafik memudahkan pengelolaan data dapat dilihat pada Gambar 13. Untuk membantu admin dalam menyediakan informasi mengenai persediaan barang didapatkan hasil yakni 4 dari 30 responden (13\%) menyatakan sangat baik dan 19 dari 30 responden (64\%) menyatakan baik dan 7 dari 30 responden (23\%) menyatakan cukup. Grafik gambaran dari hasil rekapitulasi penilaian sistem dapat dilihat pada Gambar 13, Gambar 14, Gambar 15, dan Gambar 16.

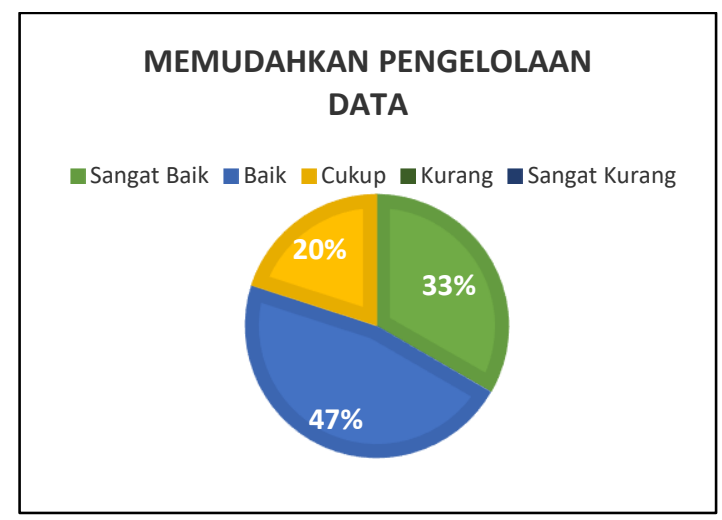

Gambar 13. Grafik Memudahkan Pengelolaan Data

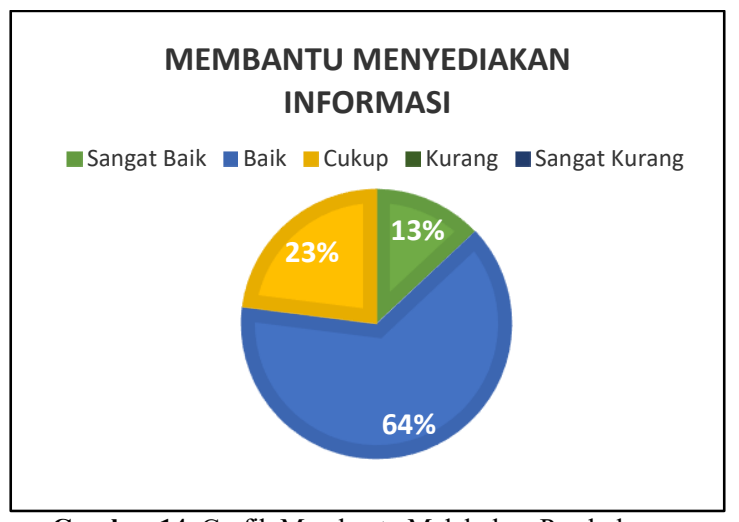

Gambar 14. Grafik Membantu Melakukan Pembukuan 


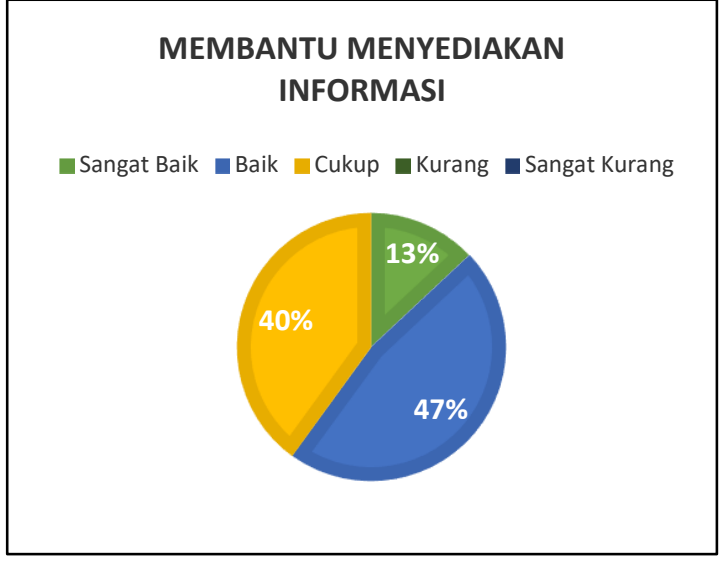

Gambar 15. Grafik Memudahkan Melakukan Permintaan

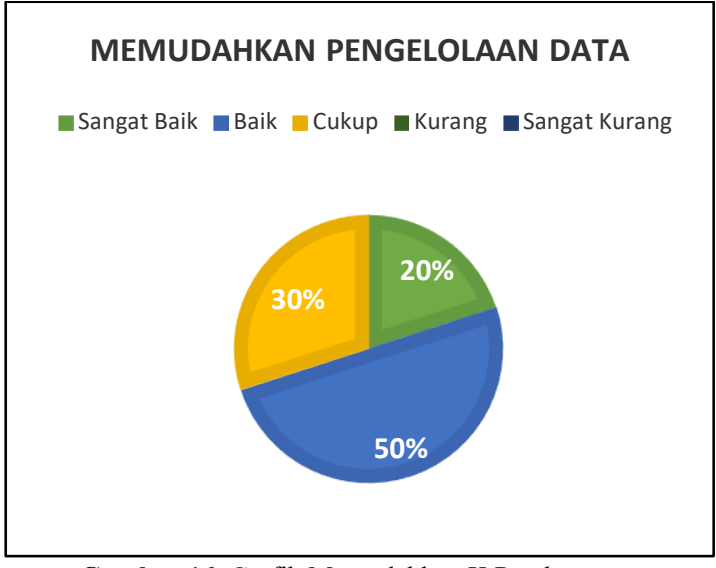

Gambar 16. Grafik Memudahkan K Pembayaran

Untuk memudahkan mitra melakukan permintaan barang berkas didapatkan hasil yakni 4 dari 30 responden (13\%) menyatakan sangat baik, 14 dari 30 responden (47\%) menyatakan baik dan 12 dari 30 responden (40\%) menyatakan cukup, grafik memudahkan pengelolaan data yang memudahkan mitra dalam proses pembayaran dan konfirmasi pembayaran. Untuk memudahkan mitra dalam melakukan proses pembayaran dan konfirmasi pembayaran didapatkan hasil yakni 6 dari 30 responden (20\%) menyatakan sangat baik, 15 dari 30 responden (50\%) menyatakan sangat baik dan 9 dari 30 responden (30\%).

\section{Kesimpulan}

Berdasarkan penelitian yang telah dilakukan, dapat ditarik kesimpulan bahwa Sistem ini membantu pihak admin perusahaan pengepul untuk proses administrasi yaitu pengelolaan pemasok rongsok, pengelolaan transaksi dan pembukuan riwayat jual beli rongsok untuk meningkatkan efektifitas kinerjanya. Sistem memudahkan mitra untuk melakukan permintaan rongsok (barang bekas), melihat stok rongsok ( barang bekas) dan proses pembayaran. Sistem dinilai cukup baik dalam mengatasi permasalahan di perusahaan pengepul berdasarkan hasil keseluruhan kuisioner untuk 30 responden bahwa 20\% menyatakan Sangat Baik, 52\% menyatakan baik, dan 28\% menyatakan cukup terhadap sistem ini. Hasil keseluruhan dengan perhitungan skala likert sebesar 77,95 masuk dalam kualifikasi Baik yang berarti berhasil. Berdasarkan hasil evaluasi Sistem Administrasi Pengepul Rongsok, maka perlu adanya penyempurnaan sistem. Untuk pengembangan sistem selanjutnya adalah adanya tambahkan fitur lokasi perusahaan pengepul, para pemasok pengepul dan mitra.

\section{Daftar Pustaka}

[1] Y. Hendra, "Perbandingan Sistem Pengelolaan Sampah di Indonesia dan Korea Selatan: Kajian 5 Aspek Pengelolaan Sampah,” Aspirasi, vol. 7, pp. 77-91, 2016, Accessed: May 10, 2021. [Online]. Available: https://jurnal.dpr.go.id/index.php/aspirasi/article/view/1281.

[2] H. Hartanto, "Sistem Pengelolaan Administrasi Pengepul Berbasis Komputer," Universitas Muhammadiyah Surakarta, 2013.

[3] M. Pomalingo, R. Yusuf, and R. H Dai, "SISTEM INFORMASI KEBERADAAN BESI BEKAS DI MASYARAKAT BERBASIS ANDROID,” Diffus. J. Syst. Inf. Technol., vol. 1, no. 1, pp. 152158, 2021, Accessed: May 10, 2021. [Online]. Available: http://ejurnal.ung.ac.id/index.php/diffusion/article/view/7818.

[4] A. S. Utomo Prawido, Arifin Ahmad, "Perancangan Sistem Informasi Pencatatan Laporan Harian Komponen Rusak Di PT.Broco Mutiara Electrical Industry,” J. Sisfotek Glob., vol. 8, no. 1, pp. 2025, Mar. 2018, doi: 10.38101/SISFOTEK.V8I1.163.

[5] D. P. Y. Ardiana, I. W. D. Suryawan, and E. Hartono, "Sistem Informasi Pengelolaan Administrasi Organisasi Kemahasiswaan Di Stmik Stikom Indonesia,” J. Teknol. Inf. dan Komput., vol. 4, no. 2, 2018, doi: 10.36002/jutik.v4i2.548.

[6] I. Sunoto, "PERANCANGAN SISTEM INFORMASI ADMINISTRASI AKADEMIK BERBASIS WEB,” Sep. 2015. doi: 10.30998/FAKTOREXACTA.V5I2.189.

[7] A. Herliana, "Analisa Dan Perancangan Sistem Informasi Administrasi Data Pribadi Dan Nilai Mahasiswa Di Perguruan Tinggi (Studi Kasus Universitas Kebangsaan Bandung),” 2016. doi: 
10.31311/ji.v1i2.41.

[8] Lilyani Asri Utami Ilmu, "Sistem Informasi Administrasi Pasien Pada Klinik Keluarga Depok," Konf. Nas. Ilmu Pengetah. dan Teknol., vol. 1, no. 1, pp. 33-38, 2015, [Online]. Available: http://konferensi.nusamandiri.ac.id/prosiding/index.php/knit/article/view/27.

[9] C. Saputra and Effiyaldi, "Analisis dan Perancangan Sistem Informasi Administrasi Kependudukan Pada Desa Kota Karang,” Manaj. Sist. Inf., vol. 2, No.3, no. 3, pp. 592-609, 2017.

[10] M. Laaziri, K. Benmoussa, S. Khoulji, and M. L. Kerkeb, "A Comparative study of PHP frameworks performance," in Procedia Manufacturing, Jan. 2019, vol. 32, pp. 864-871, doi: 10.1016/j.promfg.2019.02.295.

[11] A. Sunardi and Suharjito, "MVC architecture: A comparative study between laravel framework and slim framework in freelancer project monitoring system web based," in Procedia Computer Science, Jan. 2019, vol. 157, pp. 134-141, doi: 10.1016/j.procs.2019.08.150.

[12] R. S. Pressman, Book review: Software Engineering: a Practitioner's Approach, 5th ed., vol. 10, no. 6. Boston: McGraw-Hill, 1995.

[13] Y. SugiartI, Analisis Dan Perancangan UML (Unified Modeling Language) Generated VB.6. Yogyakarta: Graha Ilmu, 2010. 